Review

\title{
Jellyfish and Ctenophores in Limfjorden (Denmark)—Mini-Review, with Recent New Observations
}

\section{Hans Ulrik Riisgård ${ }^{1, *}$ and Josephine Goldstein ${ }^{1,2}$}

1 Marine Biological Research Centre, University of Southern Denmark, Hindsholmvej 11, DK-5300 Kerteminde, Denmark

2 Max-Planck Odense Center on the Biodemography of Aging \& Department of Biology, Campusvej 55, DK-5230 Odense M, Denmark; E-Mail: jgoldstein@biology.sdu.dk

* Author to whom correspondence should be addressed; E-Mail: hur@biology.sdu.dk; Tel.: +45-6532-1433.

External Editor: Stelios Katsanevakis

Received: 28 July 2014; in revised form: 17 September 2014 / Accepted: 29 September 2014 / Published: 14 October 2014

\begin{abstract}
Limfjorden is a major Danish water system that connects the North Sea via Thyborøn Kanal in the west and to the Kattegat in the east. Limfjorden is heavily eutrophicated and certain areas suffer from oxygen depletion each summer. Bottom-dwelling fish have disappeared as the number of jellyfish and ctenophores has increased. The abundance and predation impact of jellyfish and ctenophores in Limfjorden have been described in a number of studies conducted during the last decade, and a mini-review of this literature is given here in Section 2. The common jellyfish Aurelia aurita may, in a few years, be very abundant and exert a considerable predatory impact on zooplankton and fish larvae. Abundance, species composition, and population dynamics of A. aurita may, at irregular time intervals, be strongly influenced not only by the water brought into Limfjorden from the North Sea, but also by competition with the invasive ctenophore Mnemiopsis leidyi that occurred for the first time in extremely high numbers in 2007, brought into the fjord system with North Sea water. It has been suggested that Limfjorden may function as an incubator for M. leidyi with the potential to further seed M. leidyi into the Kattegat and adjacent Danish waters, and recent observations seem to support this hypothesis. In Section 3, we report on two bloom events of ctenophores,
\end{abstract}


Pleurobrachia pileus and M. leidyi, along with their predators (Beroe spp.) in Limfjorden in the autumns of 2012 and 2013, when the usually dominating A. aurita was absent. However, the present observation of $B$. ovata being M. leidyi's native predator and a new species in Limfjorden may in the future reduce the abundance of $M$. leidyi.

Keywords: jellyfish; Aurelia aurita; ctenophores; Mnemiopsis leidyi; Beroe ovata; predation impact; hydrography; zooplankton; Limfjorden

\section{Introduction}

Limfjorden (Denmark) is not a true fjord, but a $1500 \mathrm{~km}^{2}$ water system that connects the North Sea via Thyborøn Kanal in the west with the Kattegat in the east (Figure 1). It consists of several basins that are separated by shallow waters or narrow sounds. The mean depth is $4.9 \mathrm{~m}$, and maximum depth is $28 \mathrm{~m}$. The tidal amplitude is 10 to $20 \mathrm{~cm}$, and vertical mixing is mainly wind driven. A dominating strong west-easterly wind creates an eastward current that brings high salinity (usually $>30 \mathrm{psu}$ ) North Sea water into Limfjorden, which also receives freshwater from the surrounding land area. This results in a salinity gradient from west to east and brackish water (20-25 psu) in the inner parts [1-4]. Inflowing water to Limfjorden usually origins from the Jutland Coastal Current that flows northwards along the Danish western coast, carrying mixed water masses from the English Channel and the southern North Sea [5-8]. The water exchange in Limfjorden is mainly caused by 50 to 70 yearly incidents where strong westerly winds press North Sea water through Thyborøn Kanal into Limfjorden and which are then followed by backflow of water from Limfjorden into the North Sea during more calm weather situations (Figure 2). Every year, about $70 \mathrm{~km}^{3}$ of North Sea water enters into Limfjorden via Thyborøn Kanal, and about $65 \%$ of this water flows eastwards into the central parts that additionally receive about $3 \mathrm{~km}^{3}$ freshwater so that approximately $8.7 \mathrm{~km}^{3}$ on a yearly basis runs eastwards to Kattegat [8]. The generally poor oxygen conditions and yearly mass killing of the benthic animals (i.e., fish food) may explain the disappearance of bottom-dwelling (demersal) fish. Fisheries monitoring in the period 1980-2009 showed that the total catch of certain demersal fish species (plaice, flounder, eelpout, eel, and bullhead) in a standard trawl rapidly decreased from 1980 to 1993 whereupon virtually no fish were caught ([9], Figure 10 therein). In the same period, the abundance and thus the ecological importance of jellyfish seem to have increased, but the two phenomena are not directly linked. Thus far, the demersal fish populations have not shown any sign of recovery, even though commercial fishing was given up in the 1970s. The steep reduction in the abundance of demersal fish is probably caused by a combined effect of oxygen depletion, predation impact by cormorants and seals [10], and in the case of plaice, also less recruitment to Limfjorden due to a reduced population in the North Sea [8]. 
Figure 1. Locations of sampling sites in Limfjorden (Denmark) where ctenophores were collected on cruises during 2013. 1 = Nissum Bredning (56 $\left.34^{\prime} 25.80^{\prime \prime} \mathrm{N}, 08^{\circ} 29^{\prime} 41.40^{\prime \prime} \mathrm{E}\right)$,

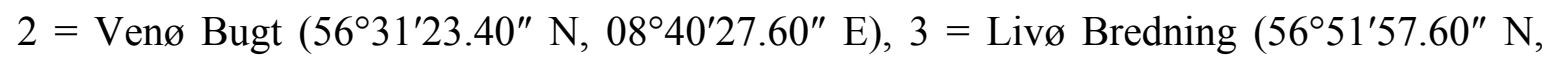
0902'57.00" E), 4 = Løgstør Bredning (56 57'09.00" N, 0903'27.60" E), 5 = Skive Fjord $\left(56^{\circ} 37^{\prime} 15.00^{\prime \prime} \mathrm{N}, 09^{\circ} 05^{\prime} 33.00^{\prime \prime} \mathrm{E}\right)$. The path of water exchange between the North Sea in west and Kattegat in the east is indicated by a broken line.

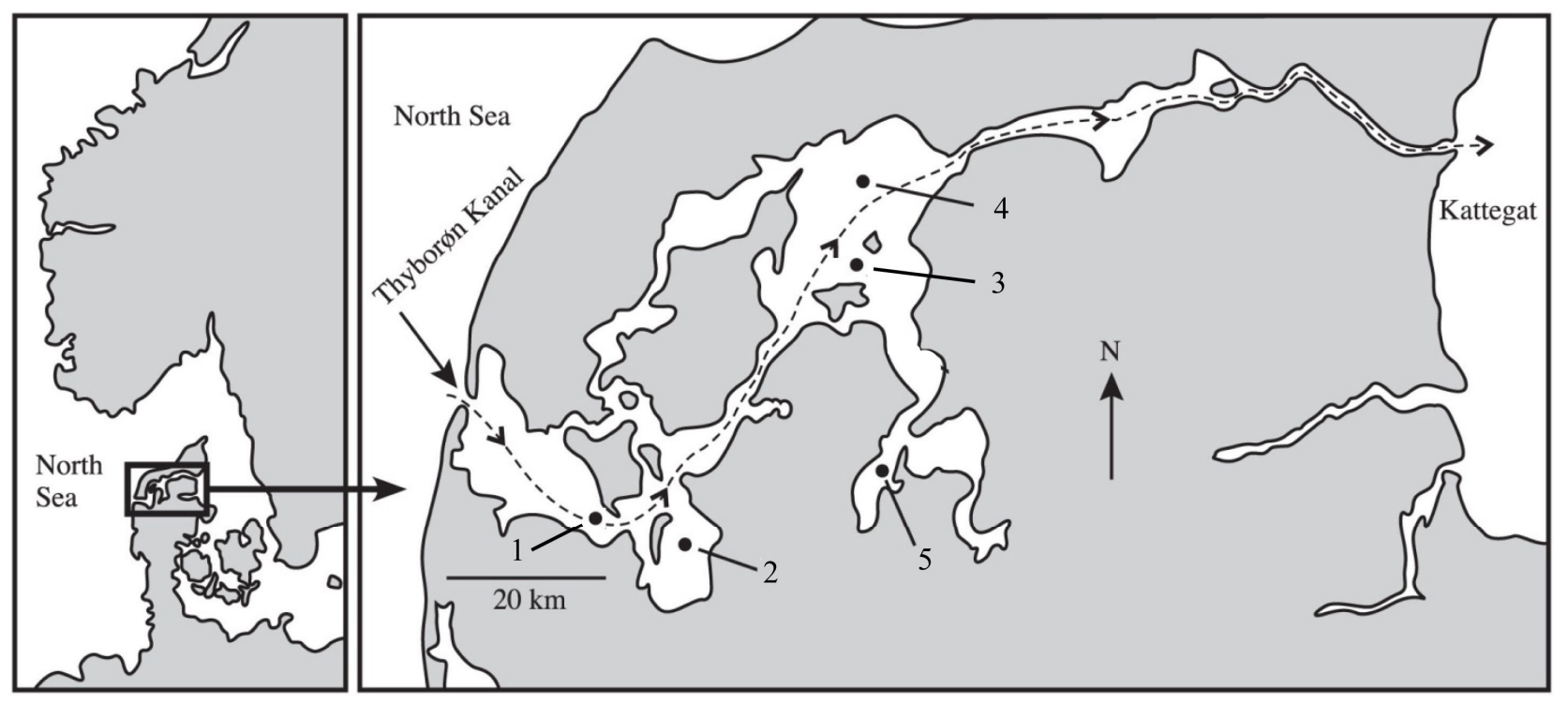

Figure 2. Water exchange in Limfjorden is mainly caused by strong westerly winds inducing intrusions of North Sea water through Thyborøn Kanal (Figure 1) and subsequent backflow of water during periods with more calm weather. The figure shows the daily water exchange rates through Thyborøn Kanal during the period 1 August to 16 November 2011. Incidents of three intrusions of water from the North Sea between the end of August to the middle of September 2011 are indicated (1-3). Easterly currents are indicated with positive values on the y-axis. From Riisgård et al. [8].

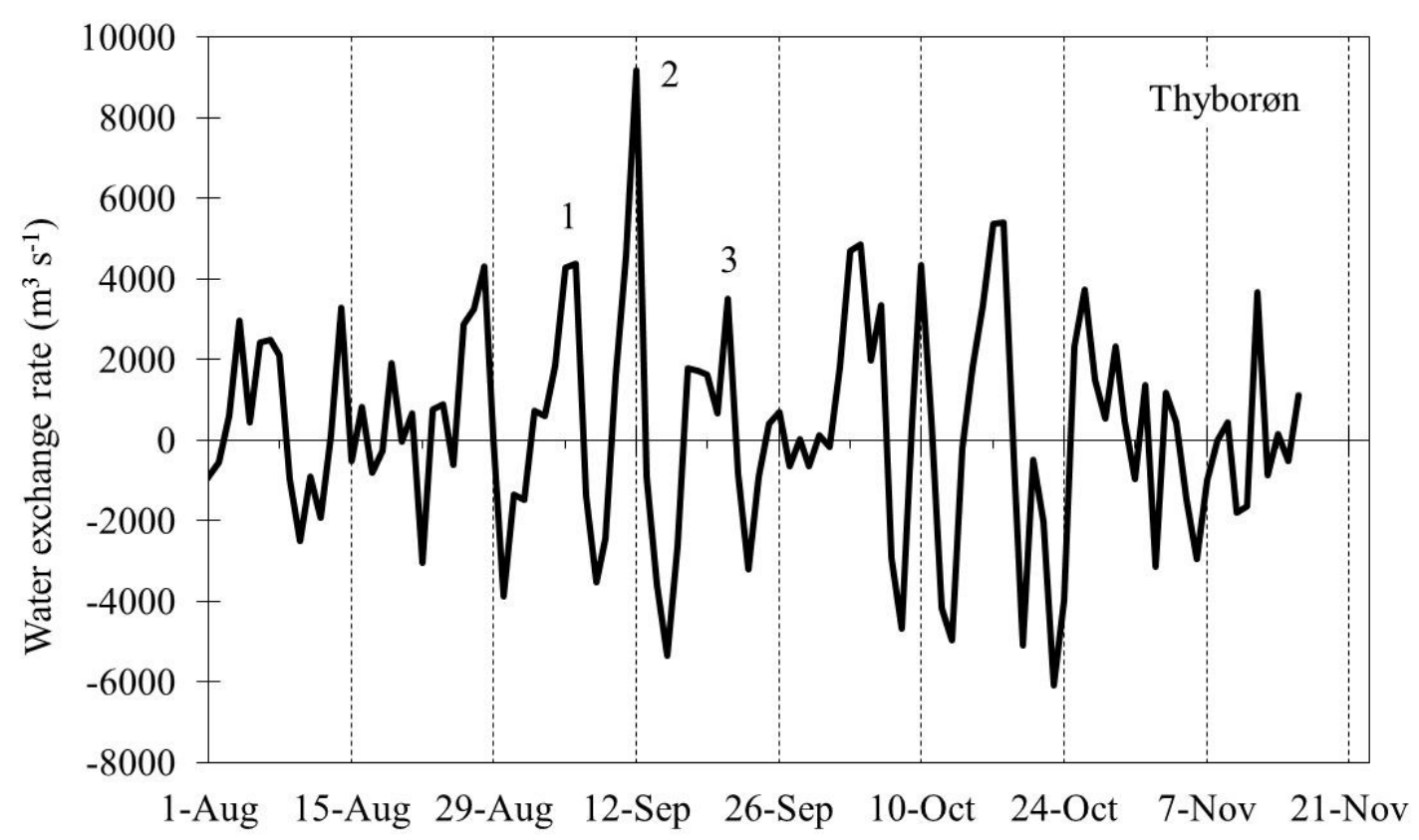


The abundance and predation impact of jellyfish and ctenophores in Limfjorden have been described by Hansson et al. [11], Møller and Riisgård [12-14] and Riisgård et al. [8,9,15,16]. It has become clear that the abundance, species composition, and population dynamics of jellyfish and ctenophores in Limfjorden are strongly influenced by hydrographical events. However, differences in life cycles also seem to be important for a better understanding of the often pronounced variations in species composition and their abundances. The scyphozoan Aurelia aurita has a metagenetic life cycle, including a pelagic medusa and a benthic polyp stage. Medusae reproduce sexually and larval development is followed by disappearance of medusae from the water column. After successful settlement, planula larvae metamorphose into polyps [17]. The polyps apparently thrive well in Limfjorden, and in the early spring, the polyps may inject the water column with ephyrae that develop into the new yearly generation of medusae [11]. Unless they are washed out of the fjord system, this frequently results in a yearly mass occurrence of jellyfish [14]. Conversely, the ctenophore Mnemiopsis leidyi relies on a holopelagic life cycle. M. leidyi is a self-fertilizing hermaphrodite, releasing eggs and sperm in the ambient water where fertilization occurs; high fecundity and rapid generation times may explain its ability to occur in large numbers [18-20]. Against this background, it is possible to understand the often large variations in the abundances of jellyfish and ctenophores in Limfjorden.

Here we first give a mini-review of studies on jellyfish and ctenophores in Limfjorden conducted with participation of the present first author during the last decade. Next, we give a brief presentation of more recent observations of two boom incidents of ctenophores, Pleurobrachia pileus and Mnemiopsis leidyi, along with their predators (Beroe spp.) in Limfjorden in the autumns of 2012 and 2013 where the usually dominating Aurelia aurita was absent. Section 3 also gives definitions and formulas for clearance rates and half-life of zooplankton frequently referred to in Section 2. The overall objective is to illustrate the importance of combined field and laboratory studies for obtaining new insight into the dynamic interplay between ctenophores and jellyfish, their predation impact, ecological consequences, and the importance of hydrography for shifts in population dynamics.

\section{Mini-Review of Jellyfish and Ctenophores in Limfjorden}

\subsection{Jellyfish Population Dynamics, Growth, and Predation Impact (2003-2005)}

The potential predation impact exerted by jellyfish on zooplankton and fish larvae in Limfjorden was assessed for the first time during the spring and summer of 2003 by Hansson et al. [11]. This was done by repeated sampling of zooplankton, fish larvae and medusae during the season, combining estimates of jellyfish abundance with experimentally measured individual clearance rates to calculate the jellyfish-induced mortality of prey organisms. Nine hydromedusae and four scyphomedusae were taxonomically identified from field samples, and copepods were used as a model prey group to estimate the joint predation impact by all medusae. Limfjorden was numerically dominated by hydromedusae, exerting their maximum potential clearance impact in spring, when the overall predatory impact by jellyfish on copepods was low. From May, the scyphomedusa Aurelia aurita was the most abundant predator on the local zooplankton community, revealing high potential to control the abundance of cirripede nauplii and fish larvae. Half-life expectancy of these prey groups was less 
than 1 day in several parts of Limfjorden. Analyses of in situ gut contents of A. aurita revealed strong variation in estimated clearance rates (i.e., volume of water cleared of prey organisms per unit of time) for different types of prey. High clearance rates were observed for large crustaceans with low escape capabilities (e.g., cirripede nauplii), whereas copepodites, copepod nauplii and small bivalve larvae were cleared at lower rate.

Møller and Riisgård [13] studied the population dynamics, growth and predation impact of Aurelia aurita and the two hydromedusae Sarsia tubulosa and Aequorea vitrina during 2003 to 2005. Before 2004, Aequorea vitrina was unknown in Limfjorden, where it later became very abundant during August and September [12,21]. Møller and Riisgård [12] provided data for assessing feeding and growth of $A$. aurita, S. tubulosa and A. vitrina. This was done by examining the effects of medusa size, prey concentration and prey species on feeding and growth, and by constructing carbon budgets with data obtained in controlled laboratory experiments where feeding, growth and respiration were measured simultaneously. These data were used to evaluate the degree to which the jellyfish realized their growth potential in Limfjorden, and to evaluate whether they were controlling the zooplankton. Furthermore, data on minimum concentrations of prey organisms needed for sustaining maximum growth were compared to prey concentrations in Limfjorden to evaluate the actual predation impact exerted by the jellyfish.

In growth experiments with Aurelia aurita ephyrae fed different species and concentrations of prey organisms, Møller and Riisgård [12] found that the specific growth rate increased with increasing prey concentration, and a maximum specific growth rate of about $22 \% \cdot$ day $^{-1}$ was obtained. For $A$. aurita medusae fed copepods (Acartia tonsa), maximum growth was about $8 \% \cdot \mathrm{day}^{-1}$. The minimum prey concentration resulting in maximum growth rate was 80 to $100 \mu \mathrm{g} \cdot \mathrm{C} \cdot \mathrm{L}^{-1}$ for ephyrae (depending on prey type), and about $100 \mu \mathrm{g} \cdot \mathrm{C} \cdot \mathrm{L}^{-1}$ for medusae. For $S$. tubulosa fed different prey concentrations of A. tonsa nauplii, the maximum specific growth rates were 32 and $10 \% \cdot \mathrm{day}^{-1}$ for 2 and $4 \mathrm{~mm}$ individuals, respectively, achieved at prey concentrations between 15 and $30 \mu \mathrm{g} \cdot \mathrm{C} \cdot \mathrm{L}^{-1}$. Maximum growth rates decreased with initial size in $A$. aurita and $A$. vitrina, to become approximately constant at $5 \%$ to $6 \% \cdot$ day $^{-1}$. Møller and Riisgård [13] used these findings to evaluate the degree to which A. aurita, S. tubulosa and A. vitrina realized their growth potential in Limfjorden, and they evaluated whether these jellyfish could control the zooplankton community in this fjord, or conversely, whether the biomass of zooplankton could control the growth of the jellyfish. This was done by comparing natural prey concentrations in Limfjorden with the minimum concentrations of prey needed for sustaining maximum growth of the jellyfish previously determined by Møller \& Riisgård [12].

In 2003, 2004 and 2005, Aurelia aurita ephyrae and hydromedusae were present during spring, and A. aurita was present through the entire study period in 2003 (February to August). In April 2004, all jellyfish disappeared, but in August 2004, Aequorea vitrina became abundant. In both 2004 and 2005, disappearance and reappearance of jellyfish coincided with sudden changes in the salinity caused by incoming high-saline water from the North Sea. By applying energy budgets from laboratory experiments, Møller and Riisgård [13] showed that the jellyfish realized their growth potential until August in 2003, after which negative growth was observed. In 2003, A. aurita had the potential to control the zooplankton in the central part of Limfjorden from mid-May to August (half-life times between 0.8 and 6.2 days). In this period, almost no zooplankton or fish larvae were present. Therefore, Møller and Riisgård [13] suggested that release of phytoplankton from zooplankton grazing 
control due to the predation pressure (on zooplankton) by A. aurelia might have resulted in pronounced phytoplankton blooms (with up to $60 \mu \mathrm{g} \cdot \mathrm{chl} a \cdot \mathrm{L}^{-1}$ in 2003) triggered by the release of nutrients from the sediment during periods of oxygen depletion in the near-bottom water. A. vitrina had no demonstrable effect on the zooplankton population, but probably preyed on ctenophores. Møller and Riisgård [13] found that in some years A. aurita may be very abundant in Limfjorden and exert a considerable predatory impact on zooplankton and fish larvae during the summer, and they concluded that the abundance, species composition, and population dynamics of jellyfish in Limfjorden may, at irregular time intervals, be strongly influenced by dramatic, but apparently rather unusual hydrographic events, and therefore, hydraulic processes may explain otherwise unaccountably large variations in the plankton community (including jellyfish; see Table 1 for taxon diversity observed in Limfjorden).

Table 1. Taxa of jellyfish (Hydromedusae and Scyphomedusae) and ctenophores observed in Limfjorden.

\begin{tabular}{cc}
\hline Taxa & Refs. \\
\hline Hydromedusae & {$[11]$} \\
Obelia sp. & {$[11]$} \\
Rathkea octopunctata & {$[8,11,13]$} \\
Sarsia tubulosa & {$[11]$} \\
Hybocodon prolifer & {$[11]$} \\
Bougainvillia sp. & {$[11]$} \\
Tiaropsis multicirrata & {$[11]$} \\
Phialidium hemisphaericum & {$[11]$} \\
Eutonina indicans & {$[11]$} \\
Aglantha digitale & {$[13,21]$} \\
Aequorea vitrina & \\
Scyphomedusae & {$[8,11-13,16]$} \\
Aurelia aurita & {$[11]$} \\
Cyanea lamarckii & {$[8,11]$} \\
Cyanea capillata & {$[11]$} \\
Chrysaora hysoscella & Present study \\
Rhizostoma octopus & \\
Ctenophores & {$[8,15]$} \\
Mnemiopsis leidyi & {$[8]$} \\
Pleurobrachia pileus & {$[8]$} \\
Beroe cucumis & Present study \\
Beroe ovata & Present study \\
Beroe gracilis &
\end{tabular}

\subsection{Oxygen Depletion and the Importance of Jellyfish in an Inner Branch of Limfjorden (Skive Fjord)}

The heavily eutrophicated Skive Fjord (an inner branch of Limfjorden, Figure 1) provides an illustration of the potential links between primary production, oxygen deficiency, nutrients and jellyfish [14]. Oxygen depletion occurs in the near-bottom water of Skive Fjord each summer, causing release of large amounts of nutrients (phosphate and ammonium) from the anoxic sediment. This 
results in a subsequent phytoplankton bloom, followed by increasing zooplankton biomass. During periods with severe oxygen depletion, surface chlorophyll $a$ concentrations may reach very high values, an effect that is enhanced when jellyfish (Aurelia aurita) show mass occurrence. In certain years facing such jellyfish blooms, peak concentrations as high as 60 to $80 \mu \mathrm{g} \cdot \mathrm{chl} \cdot a \cdot \mathrm{L}^{-1}$ have been measured in Skive Fjord because the jellyfish effectively eliminate the zooplankton-grazing impact on the phytoplankton bloom (Figure 3). In contrast, the grazing impact by dense populations of mussels (Mytilus edulis) can decrease phytoplankton biomass, especially in the near-bottom water. Therefore, available data on the abundance of jellyfish and mussels have been combined with data on oxygen, nutrients, chlorophyll $a$, zooplankton, and other data from various studies conducted in Skive Fjord during the period 1996-2005 [14]. The available data ([14], Figure 3 therein) indicate that especially severe cases of oxygen depletion take place in years with mass occurrence of jellyfish, severely weakening the grazing impact on algal blooms which consequently settle to the bottom to be decomposed; resulting low oxygen concentrations lead to high mussel mortality, which in turn may reinforce oxygen depletion.

Figure 3. Mass occurrence of jellyfish (Aurelia aurita) in Limfjorden (Branden, Fursund) 27 June 2010. The water is probably green because the jellyfish have eliminated the usual zooplankton-grazing impact on the phytoplankton in the eutrophicated fjord system. Photo: Hans Ulrik Riisgård.

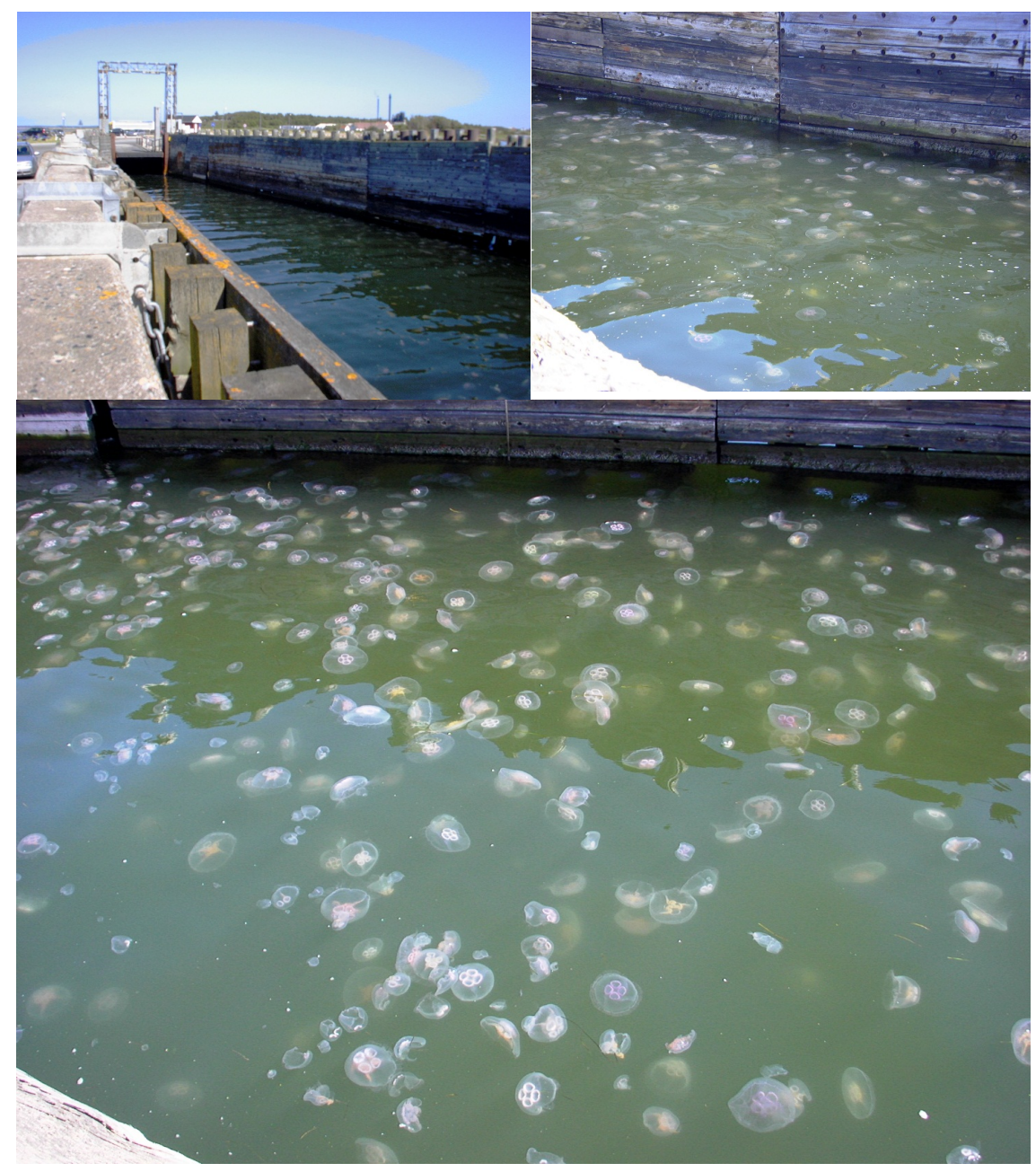




\subsection{Invasive Ctenophore Mnemiopsis leidyi (2007)}

The first occurrence of the invasive ctenophore, Mnemiopsis leidyi, in Danish waters was described by Tendal et al. [22] in 2007. Numerous sightings indicated wide distribution of the ctenophore in all inner Danish waters in the summer of 2007, and mass occurrence of M. leidyi was observed in some areas, including Limfjorden. Riisgård et al. [15] assessed the abundance of $M$. leidyi in Limfjorden in the late summer of 2007, and evaluated its predation effects on zooplankton. On two cruises in August and September, M. leidyi was found in every net sample from nine locations in Limfjorden. High population densities of up to $>800$ ind. $\cdot \mathrm{m}^{-3}$ were observed in the innermost part, showing relatively small body lengths of 5 to $15 \mathrm{~mm}$. The bio-volumes were very high, up to $300 \mathrm{~mL} \cdot \mathrm{m}^{-3}$ in the central parts of Limfjorden, which was greater than reported from the Black Sea in autumn 1989, where a maximum bio-volume of $184 \mathrm{~mL} \cdot \mathrm{m}^{-3}$ led to a collapse in zooplankton and fish stocks [23]. During the two cruises reported by Riisgård et al. [15], very few Aurelia aurita were observed, except in Skive Fjord in September 2007 when medusa density was 0.4 ind. $\cdot \mathrm{m}^{-3}$ and the mean umbrella diameter $9.7 \pm 3.0 \mathrm{~cm}$. This density was low when compared to 2.4 ind. $\mathrm{m}^{-3}$ (mean umbrella diameter $14.6 \pm$ $2.9 \mathrm{~cm}$ ) in late August 2003 [13] before M. leidyi was present. This might indicate that M. leidyi competed with $A$. aurita for food in 2007, partly taking over the trophic role of this jellyfish in the ecosystem.

\subsection{Ctenophores and Jellyfish (2008-2011)}

The new invasive Mnemiopsis leidyi and the indigenous Aurelia aurita were studied from autumn 2008 through summer 2009 in Limfjorden by Riisgård et al. [16]. By December 2008, both A. aurita and M. leidyi populations had disappeared for the winter. In 2009, the first A. aurita appeared in February and the medusae attained their maximum umbrella diameter by the end of June, when the estimated half-life of copepods was only $1.6 \pm 1.1$ days. Low densities of M. leidyi in early July $\left(<0.5 \mathrm{~m}^{-3}\right)$ increased to high densities by late August $\left(66.2\right.$ to $\left.224.9 \mathrm{ind} \cdot \mathrm{m}^{-3}\right)$. In 2009 , the estimated time to clear the central part of Limfjorden of zooplankton by $A$. aurita and M. leidyi feeding was between 0.5 days (4 June) and 2.9 days (26 August). During that period, copepods and other mesozooplankton organisms were virtually absent while ciliates were a substantial part of the zooplankton biomass ([9], Figure 14 therein). In "pre-Mnemiopsis years" there seems to have been large variability in the grazing impact on zooplankton depending on the seasonal abundance of A. aurita. With the presence of the second carnivore $M$. leidyi, however, additional predation pressure caused the zooplankton stocks to be severely depressed throughout 2008 and 2009 when copepods and cladocerans no longer showed the high seasonal peaks in abundance as typical for previous years.

The abundances of Mnemiopsis leidyi and Aurelia aurita at four sampling locations in Limfjorden were followed during several cruises in 2010 and 2011 by Riisgård et al. [8]. In 2010, M. leidyi was observed in Limfjorden for the first time in August, showing the highest density and largest size in central parts (Skive Fjord). The estimated half-life of zooplankton (copepods) was only important in Skive Fjord in mid-August 2010 when the joint predation impact of A. aurita and M. leidyi was 2.3 days. In 2011, no M. leidyi were observed on the first cruise (3 August), while it appeared in large numbers during the second cruise (17 November). The westernmost location (Venø Bugt, Figure 1) 
was dominated by large $(\leq 60 \mathrm{~mm}) M$. leidyi, while the average size decreased towards the central parts of the fjord system. An increasing proportion of cydippid larvae from the western to central parts suggested rapid expansion of the ctenophore population. The bio-volumes of ctenophores were highest in the central part with $85 \mathrm{~mL} \cdot \mathrm{m}^{-3}$ in Løgstør Bredning (Figure 1). Analysis of available hydrographic data and model calculations indicated that re-invasion of M. leidyi from the North Sea seeded the autumn population in Limfjorden in mid-September [8]. In 2011, in- and outflow through Thyborøn Kanal took place as in typical years, and likewise the eastward net flow to Kattegat was typical. Figure 2 shows the water exchange via Thyborøn Kanal in the period from 1 August to 16 November 2011, illustrating three strong inflow events from late August to mid-September. Calculations [8] showed an inflowing water volume of $3.2 \mathrm{~km}^{3}$ into Limfjorden, and by assuming that $65 \%$ of this water later entered the central parts (Løgstør Bredning), this outlined that $2.1 \mathrm{~km}^{3}$ North Sea water were pressed into this shallow area. Profile measurements from Løgstør Bredning from 3 to 16 August 2011 showed a salinity of about $27.1 \mathrm{psu}$. As an effect of the first of the aforementioned three inflow events (Figure 2), the salinity was approximately 28 psu in the surface layer and $28.6 \mathrm{psu}$ at the sea floor on 31 August. On 4 September the salinity had decreased to 27.7 psu, and after two further intrusions of North Sea water (Figure 2), salinity had increased to 28.8 psu on 20 September, coinciding with the first observation of M. leidyi in 2011 in Løgstør Bredning. Simultaneous measurements of the salinity profile in Skive Fjord showed a $2 \mathrm{~m}$ thick bottom water layer of almost 28 psu from Løgstør Bredning. The hydrographic observations and model calculations [8] indicate that $M$. leidyi was brought into Limfjorden during mid-September via Jutland Coastal Current water from the North Sea, carrying water masses from the English Channel and the southern North Sea where M. leidyi can be numerous [24-26].

\section{Ctenophores in Limfjorden-Boom Incidents in 2012 and 2013}

\subsection{Introduction}

Here we report on two boom incidents of ctenophores, Pleurobrachia pileus and Mnemiopsis leidyi, along with their predators (Beroe spp.) in Limfjorden in the autumns of 2012 and 2013 where the usually dominating Aurelia aurita was absent. Field work in 2013 had only been possible through an extraordinary collaboration with the Danish Marine Home Guard, and not as in the preceding years 2003-2012 with a research vessel with CTD and other oceanographic equipment. This caused a different sampling technique in 2013, but nevertheless some important observations were made and are therefore reported here to supplement the preceding mini-review.

\subsection{Materials and Methods}

\subsubsection{Field Investigations}

2012: Ctenophores were collected with a $2 \mathrm{~mm}$ meshed plankton net $\left(1.77 \mathrm{~m}^{2}\right.$ mouth area $)$ in Løgstør Bredning (Figure 1) in Limfjorden during two cruises with "Limgrim" on 2 October and 28 November 2012, respectively. The net was equipped with a closed cod end bucket to prevent damage of the gelatinous plankton. At the sampling location, three hauls were made by obliquely raising the 
net from the bottom to the surface at a speed of 1.5 knots for population density estimates. After each haul, the number of ctenophores in the net-bucket was counted. The mean $( \pm \mathrm{SD})$ population density of ctenophores was estimated from the density in the three hauls. Furthermore, the mean $( \pm \mathrm{SD})$ size of Pleurobrachia pileus (polar body length of about 30 individuals) was measured to the nearest $\mathrm{mm}$ by using a stereo-microscope, whereas the mean size of Mnemiopsis leidyi was determined by measuring the distance between mouth and opposite pole (oral-aboral length) on 50 individuals with a Vernier caliper. The total bio-volume $B$ of ctenophores present in each haul was determined by measuring the seawater-free samples in a graduated beaker.

2013: Ctenophores were collected with a net (see above) at five locations in Limfjorden (Figure 1) during cruises with the Danish Marine Home Guard ship. Three hauls per station (haul length $\sim 300 \mathrm{~m}$ ) were performed at a water depth of approximately $1 \mathrm{~m}$ at a speed of $0.5-1.0$ knots for population density estimates. After the three hauls, the ctenophores in the net-bucket were counted from sub-samples. Mean $( \pm \mathrm{SD})$ population densities were estimated from the volume of water filtered per haul as derived from net area and haul length Lhaul, with the latter being calculated from hauling speed over known time. The total bio-volume of ctenophores present in each haul was determined by measuring the seawater-free samples in a graduated beaker. Furthermore, the mean $( \pm \mathrm{SD})$ size of ctenophores (diameter of about 50 individuals) was determined to the nearest $\mathrm{mm}$ by measuring the distance between mouth and opposite pole (oral-aboral length).

\subsubsection{Clearance Rates and Half-Life of Prey}

Equations used in the present work have been used previously and described in more detail by Riisgård et al. $[8,16]$ along with statements for their premises and limitations.

(A) Pleurobrachia pileus. Clearance rates $\left(\mathrm{Cl}_{\text {ind }}, \mathrm{L} \cdot \mathrm{day}^{-1}\right)$ were estimated by use of the following equation for ctenophores feeding on copepods [27]:

$$
C l_{\text {ind }}=0.2 L^{1.9}
$$

where $L(\mathrm{~mm})$ equals the polar length. The volume-specific population clearance rate $\left(C l_{p o p}, \mathrm{~m}^{3}\right.$ water filtered by the ctenophore population in one $\mathrm{m}^{3}$ water per day $=\mathrm{m}^{3} \cdot \mathrm{m}^{-3} \cdot \mathrm{day}^{-1}$ ) was estimated as the product of the individual clearance rate $\left(C l_{\text {ind }}, \mathrm{L} \cdot\right.$ day $\left.^{-1}\right)$ and the population density $\left(D\right.$, ind $\left.\cdot \mathrm{m}^{-3}\right)$ :

$$
C l_{\text {pop }}=C l_{\text {ind }} \times D / 1000
$$

(B) Mnemiopsis leidyi. The following relationship was used for converting oral-aboral length $(L, \mathrm{~mm})$ to individual body volume $(V, \mathrm{~mL})[15]$ :

$$
V=0.0226 L^{1.72}
$$

The following equation (presented by Riisgård et al. [16] and based on Decker et al. [28]) was used to estimate the individual clearance rate $\left(C l_{\text {ind }}, \mathrm{L} \cdot \mathrm{day}^{-1}\right)$ of ctenophores feeding on copepods as a function of their body volume $(V, \mathrm{~mL})$ :

$$
C l_{\text {ind }}=2.64 \mathrm{~V}
$$


The volume-specific population clearance rate $\left(C l_{p o p}, \mathrm{~m}^{3}\right.$ water filtered by the ctenophore population in one $\mathrm{m}^{3}$ water per day $=\mathrm{m}^{3} \cdot \mathrm{m}^{-3} \cdot$ day $^{-1}$ ) was estimated as the product of the individual clearance rate $\left(C l\right.$ ind, $\left.\mathrm{L} \cdot \mathrm{day}^{-1}\right)$ and the population density $\left(D\right.$, ind. $\left.\cdot \mathrm{m}^{-3}\right)$ for each locality:

$$
C l_{\text {pop }}=C l_{\text {ind }} \times D / 1000
$$

The time ( $t_{1 / 2}$, day) it takes for a population of jellyfish/ctenophores with known $C l_{p o p}$ to reduce the concentration of prey organisms (copepods) in $V=1 \mathrm{~m}^{3}$ of water by $50 \%$ (i.e., the half-life of prey) was estimated as (Riisgård et al. [16]):

$$
t_{1 / 2}=\ln 2 / C l_{p o p}
$$

\subsection{Results and Discussion}

\subsubsection{Cruises in 2012}

\subsubsection{Cruise 1 (2 October 2012)}

The data for Pleurobrachia pileus are shown in Table 2 . The density was $157 \pm 45 \mathrm{ind} \cdot \mathrm{m}^{-3}$ and the estimated half-life of zooplankton (copepods) was short-only 1.5 day-thus indicating that the ctenophore controlled the zooplankton biomass in Løgstør Bredning in early October 2012. Only one small individual of Mnemiopsis leidyi was caught in Løgstør Bredning (Figure 4).

Table 2. Pleurobrachia pileus collected in Løgstør Bredning 2 October 2012. Lhaul = haul length; $V_{f}=$ volume filtered per haul; $N=$ total number of individuals caught; $D=$ population density; $L=$ polar body length; $C l_{\text {ind }}=$ individual clearance rate (Equation (1)); $C l_{p o p}=$ population clearance rate (Equation (2)); $t_{1 / 2}=$ estimated half-life of

\begin{tabular}{|c|c|c|c|c|c|c|c|c|}
\hline Cruise/Date/Locality & $\begin{array}{r}L_{\text {haul }} \\
\text { (m) }\end{array}$ & $\begin{array}{c}V_{f} \\
\left(\mathbf{m}^{3}\right)\end{array}$ & $\begin{array}{c}N \\
\text { (ind.) }\end{array}$ & $\begin{array}{c}D \\
\text { (ind. } \cdot \mathbf{m}^{-3} \text { ) }\end{array}$ & $\begin{array}{c}L \\
(\mathrm{~mm})\end{array}$ & $\begin{array}{c}C l_{\text {ind }} \\
(\mathrm{L} \\
\left.\cdot \operatorname{day}^{-1}\right) \\
\end{array}$ & $\begin{array}{c}C l_{p o p} \\
\left(\mathbf{m}^{3} \cdot \mathrm{day}^{-1}\right)\end{array}$ & $\begin{array}{c}t / 1 / 2 \\
\text { (day) }\end{array}$ \\
\hline \multicolumn{9}{|l|}{ Cruise $1 *$} \\
\hline \multicolumn{9}{|l|}{2 October 2012} \\
\hline Løgstør Bredning & $163 \pm 85$ & $289 \pm 151$ & $41,420 \pm 11,116$ & $157 \pm 45$ & $4.1 \pm 1.1$ & 2.9 & 0.46 & 1.5 \\
\hline \multicolumn{9}{|l|}{ Cruise $2 * *$} \\
\hline \multicolumn{9}{|l|}{28 November 2012} \\
\hline Løgstør Bredning & $203 \pm 53$ & $358 \pm 94$ & $11,400 \pm 2,687$ & $31.9 \pm 0.9$ & $6.9 \pm 0.8$ & 7.9 & 0.25 & 2.8 \\
\hline
\end{tabular}
copepods (Equation (6)). Mean $\pm \mathrm{SD}$ are shown.

In mid-September, the hydromedusa Aequorea vitrina and the scyphozoan jellyfish Rhizostoma octopus had been observed in Limfjorden (Figure 5) and this indicates, along with high salinities (up to 29 psu measured in Løgstør Bredning), that a large volume of high-saline North Sea water had been pushed in through Thyborøn Kanal by strong westerly winds, and therefore it may be suggested that Pleurobrachia pileus was brought into Limfjorden from the North Sea. 
Figure 4. (left) Pleurobrachia pileus; (right) Mnemiopsis leydi collected in Løgstør Bredning 2 October 2012. Interval on scale $=$ mm. Photo: Hans Ulrik Riisgård.
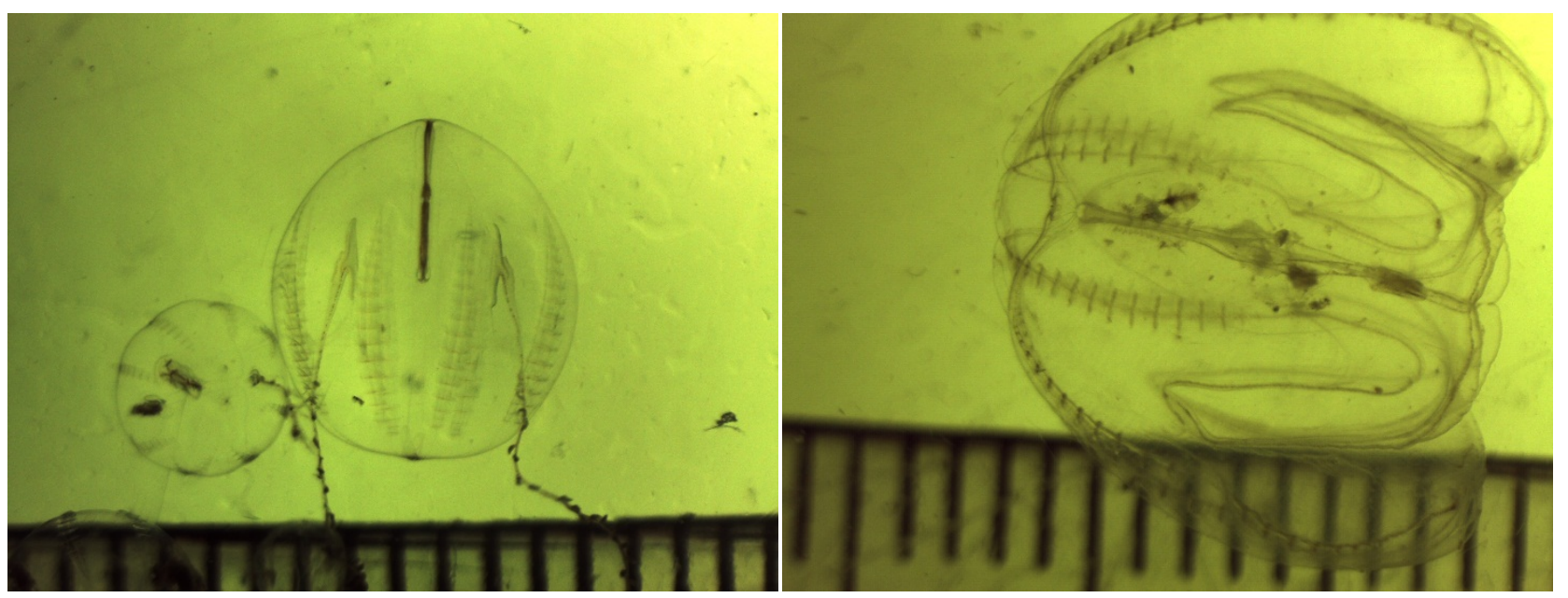

\subsubsection{Cruise 2 (28 November 2012)}

The data for Pleurobrachia pileus and Mnemiopsis leidyi (Figure 5) are shown in Tables 2 and 3, respectively. It appears from Table 2 that the half-life of zooplankton was short, 2.8 days, indicating that $P$. pileus was still able control the zooplankton in Løgstør Bredning whereas the predation impact of M. leidyi was insignificant (Table 3).

Table 3. Mnemiopsis leidyi collected in Løgstør Bredning 28 November 2012. Lhaul $=$ haul length; $V_{f}=$ volume filtered per haul; $N=$ total number of individuals caught; $D=$ population density; $L=$ oral-aboral body length; $V=$ estimated individual body volume (Equation (3)); $C l_{\text {ind }}=$ individual clearance rate (Equation (4)); $C l_{p o p}=$ population clearance rate (Equation (5)); $t_{1 / 2}=$ estimated half-life of copepods (Equation (6); $t_{1 / 2}>3$ weeks is indicated by $\infty$ ). Mean \pm SD are shown.

\begin{tabular}{|c|c|c|c|c|c|c|c|c|c|}
\hline $\begin{array}{c}\text { Cruise/Date/ } \\
\text { Locality }\end{array}$ & $\begin{array}{l}L_{\text {haul }} \\
\text { (m) }\end{array}$ & $\begin{array}{c}V_{f} \\
\left(\mathrm{~m}^{3}\right)\end{array}$ & $\begin{array}{c}N \\
\text { (ind.) }\end{array}$ & $\begin{array}{c}D \\
\text { (ind. } \cdot \mathbf{m}^{-3} \text { ) }\end{array}$ & $\begin{array}{c}L \\
(\mathrm{~mm})\end{array}$ & $\begin{array}{c}V \\
\left(\mathbf{m L} \cdot \text { ind }^{-1}\right)\end{array}$ & $\begin{array}{c}C l_{\text {ind }} \\
\left(\mathrm{L} \cdot \text { day }^{-1}\right)\end{array}$ & $\begin{array}{c}C l_{p o p} \\
\left.{ }^{3} \cdot \mathbf{m}^{-3} \cdot \mathrm{day}^{-1}\right)\end{array}$ & $\begin{array}{c}t_{1 / 2} \\
\text { (day) }\end{array}$ \\
\hline \multicolumn{10}{|l|}{ Cruise 2} \\
\hline \multicolumn{10}{|l|}{28 November 2012} \\
\hline Løgstør Bredning & $203 \pm 53$ & $358 \pm 94$ & $185 \pm 134$ & $0.5 \pm 0.2$ & $19.2 \pm 1.8$ & 3.6 & 9.6 & 0.005 & $\infty$ \\
\hline
\end{tabular}

The significant predation impact of Pleurobrachia pileus in both October and November 2012 along with the relatively few Mnemiopsis leidyi indicates meager feeding conditions for the latter due to interspecific competition. 
Figure 5. Jellyfish from the North Sea observed in Limfjorden. (A) Rhizostoma octopus caught in Limfjorden (Risgårde Bredning) 17 September 2012 by DTU-Aqua during a fisheries monitoring survey. Photo: Erik Hoffmann; (B) Stranded R. octopus on the beach near Glyngøre, Limfjorden, on 7 September 2013. Note the characteristic jagged purple bell edge and reddish oral arms. Photo: Joan Thora E. Laurberg. (C,D) R. octopus stranded on the beach (Lysen Bredning, near Salling Sund, Limfjorden) 22 September 2013. Photo: Hans Ulrik Riisgård.

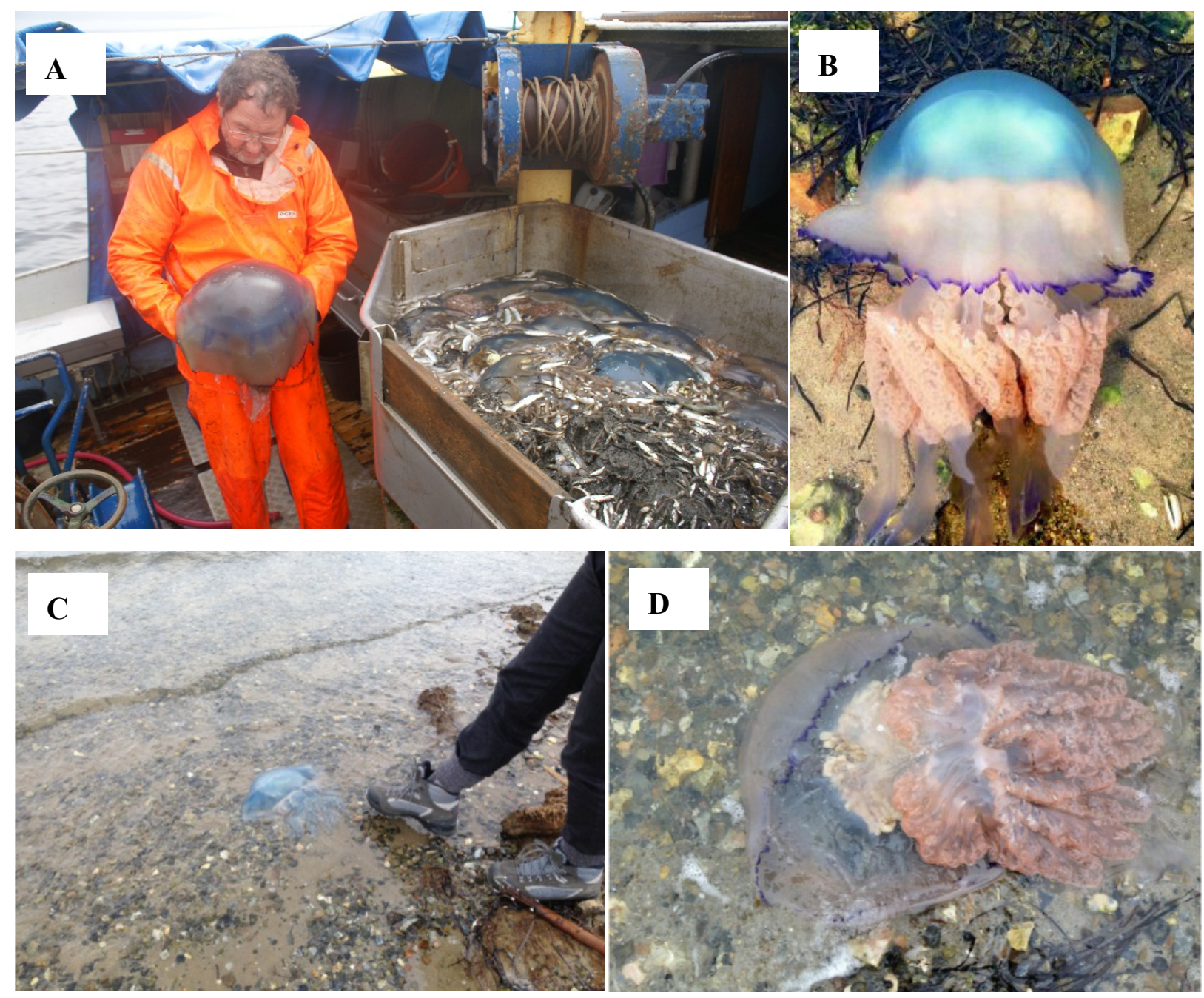


Table 4. Mnemiopsis leidyi collected during three cruises in Limfjorden in 2013. Lhaul $=$ haul length; $V_{f}=$ volume filtered per haul; $N=$ total number of individuals caught; $D=$ population density; $L=$ oral-aboral body length; $V=$ estimated individual body volume (Equation (3)); $B=$ measured total bio-volume of ctenophore population; $C l_{\text {ind }}=$ individual clearance rate (Equation (4)); $C l_{p o p}=$ population clearance rate (Equation (5)); $t_{1 / 2}=$ estimated half-life of copepods (Equation (6); $t_{1 / 2}>3$ weeks are indicated by $\infty$ ). Mean \pm SD are shown.

\begin{tabular}{|c|c|c|c|c|c|c|c|c|c|c|}
\hline Cruise/Date/Locality & $\begin{array}{l}L_{\text {haul }} \\
\text { (m) }\end{array}$ & $\begin{array}{c}V_{f} \\
\left(\mathbf{m}^{3}\right)\end{array}$ & $\begin{array}{c}N \\
\text { (ind.) }\end{array}$ & $\begin{array}{c}D \\
\text { (ind. } \cdot \mathbf{m}^{-3} \text { ) } \\
\end{array}$ & $\begin{array}{c}L \\
(\mathrm{~mm})\end{array}$ & $\begin{array}{c}V \\
\left(m L \cdot \text { ind }^{-1}\right)\end{array}$ & $\begin{array}{c}B \\
\left(\mathbf{m L} \cdot \mathbf{m}^{-3}\right) \\
\end{array}$ & $\begin{array}{c}C l_{\text {ind }} \\
\left(\mathbf{L} \cdot \text { day }^{-1}\right)\end{array}$ & $\begin{array}{c}C l_{p o p} \\
\left(\mathbf{m}^{3} \cdot \mathrm{m}^{-3} \cdot \mathbf{d a y}^{-1}\right) \\
\end{array}$ & $\begin{array}{c}t / 2 \\
\text { (day) }\end{array}$ \\
\hline \multicolumn{11}{|l|}{ Cruise 1} \\
\hline \multicolumn{11}{|l|}{23 September 2013} \\
\hline 1 Nissum Bredning & $107 \pm 0$ & $190 \pm 0$ & $12,172 \pm 4077$ & $64 \pm 22$ & $29.6 \pm 11.3$ & 7.65 & $9.0 \pm 0.9$ & 20.2 & 1.296 & 0.5 \\
\hline 2 Venø Bugt & $299 \pm 197$ & $529 \pm 348$ & $996 \pm 350$ & $2 \pm 1$ & $28.5 \pm 12.7$ & 7.17 & $9.5 \pm 4.5$ & 18.9 & 0.041 & 17.0 \\
\hline 3 Livø Bredning & $94 \pm 46$ & $166 \pm 82$ & $9058 \pm 2645$ & $59 \pm 18$ & $7.5 \pm 3.2$ & 0.73 & $18.2 \pm 4.6$ & 1.9 & 0.113 & 6.2 \\
\hline 4 Løgstør Bredning & $67 \pm 0$ & $119 \pm 0$ & $5024 \pm 714$ & $42 \pm 6$ & $9.5 \pm 4.0$ & 1.08 & $17.7 \pm 2.5$ & 2.9 & 0.121 & 5.7 \\
\hline 5 Skive Fjord & $54 \pm 12$ & $95 \pm 21$ & $24,212 \pm 7041$ & $254 \pm 48$ & $6.1 \pm 2.5$ & 0.51 & $47.9 \pm 3.3$ & 1.3 & 0.339 & 2.1 \\
\hline \multicolumn{11}{|l|}{ Cruise 2} \\
\hline \multicolumn{11}{|l|}{23 October 2013} \\
\hline 1 Nissum Bredning * & - & - & - & - & - & - & - & - & - & - \\
\hline 2 Venø Bugt & $134 \pm 23$ & $237 \pm 41$ & $475 \pm 357$ & $2 \pm 1$ & $26.7 \pm 11.4$ & 6.41 & $6.8 \pm 5.6$ & 16.9 & 0.032 & $\infty$ \\
\hline 3 Livø Bredning * & - & - & - & - & - & - & - & - & - & - \\
\hline 4 Løgstør Bredning & $81 \pm 23$ & $143 \pm 41$ & $2043 \pm 188$ & $15 \pm 5$ & $7.4 \pm 2.7$ & 0.70 & - & 1.9 & 0.028 & $\infty$ \\
\hline 5 Skive Fjord * & - & - & - & - & - & - & - & - & - & - \\
\hline \multicolumn{11}{|l|}{ Cruise 3} \\
\hline \multicolumn{11}{|l|}{20 November 2013} \\
\hline 1 Nissum Bredning & $161 \pm 57$ & $284 \pm 100$ & $431 \pm 49$ & $2 \pm 1$ & $30.8 \pm 9.1$ & 8.23 & $7.9 \pm 2.5$ & 21.7 & 0.035 & 19.7 \\
\hline 2 Venø Bugt & $363 \pm 77$ & $642 \pm 136$ & $552 \pm 321$ & $1 \pm 0$ & $32.3 \pm 9.3$ & 8.89 & $3.2 \pm 1.1$ & 23.5 & 0.020 & $\infty$ \\
\hline 3 Livø Bredning & - & - & - & - & - & - & - & - & - & - \\
\hline 4 Løgstør Bredning & $247 \pm 150$ & $437 \pm 265$ & $5189 \pm 1281$ & $14 \pm 6$ & $10.4 \pm 5.4$ & 1.27 & $8.3 \pm 3.7$ & 3.3 & 0.047 & 14.7 \\
\hline 5 Skive Fjord & $111 \pm 0$ & $197 \pm 0$ & $4,295 \pm 827$ & $22 \pm 4$ & $6.5 \pm 3.9$ & 0.56 & $4.4 \pm 0.2$ & 1.5 & 0.032 & $\infty$ \\
\hline
\end{tabular}

* Jellyfish net lost. 
Table 5. Other ctenophore species than Mnemiopsis leidyi (cf. Table 4) collected during three cruises in Limfjorden in 2013. Lhaul $=$ haul length; $V_{f}=$ volume filtered per haul; $N=$ total number of individuals caught; $D=$ population density; $L=$ oral-aboral body length. Mean \pm SD are shown.

\begin{tabular}{|c|c|c|c|c|c|c|c|c|}
\hline \multirow{2}{*}{ Cruise/Date/Locality } & \multirow{2}{*}{$L_{\text {haul }}(\mathrm{m})$} & \multirow{2}{*}{$V_{f}\left(\mathbf{m}^{3}\right)$} & \multicolumn{3}{|c|}{ Pleurobrachia pileus } & \multicolumn{3}{|c|}{ Beroe spp. } \\
\hline & & & $N$ (ind.) & $D$ (ind. $\cdot m^{-3}$ ) & $L(\mathrm{~mm})$ & $N$ (ind.) & $D$ (ind. $\cdot m^{-3}$ ) & $L(\mathrm{~mm})$ \\
\hline \multicolumn{9}{|l|}{ Cruise 1} \\
\hline \multicolumn{9}{|l|}{23 September 2013} \\
\hline 1 Nissum Bredning & $107 \pm 0$ & $190 \pm 0$ & $2 \pm 3$ & $0.012 \pm 0.013$ & $10.5 \pm 0.7$ & $3 \pm 2$ & $0.014 \pm 0.012$ & $11.7 \pm 0.6 * *$ \\
\hline 2 Venø Bugt & $299 \pm 197$ & $529 \pm 348$ & 0 & 0 & - & 0 & 0 & - \\
\hline 3 Livø Bredning & $94 \pm 46$ & $166 \pm 82$ & 0 & 0 & - & 0 & 0 & - \\
\hline 4 Løgstør Bredning & $67 \pm 0$ & $119 \pm 0$ & 0 & 0 & - & 0 & 0 & - \\
\hline 5 Skive Fjord & $54 \pm 12$ & $95 \pm 21$ & 0 & 0 & - & 0 & 0 & - \\
\hline \multicolumn{9}{|l|}{ Cruise 2} \\
\hline \multicolumn{9}{|l|}{23 October 2013} \\
\hline 1 Nissum Bredning * & - & - & - & - & - & - & - & - \\
\hline 2 Venø Bugt & $134 \pm 23$ & $237 \pm 41$ & $0.3 \pm 0.6$ & $0.001 \pm 0.002$ & $9.0 \pm 0$ & $2 \pm 1$ & $0.008 \pm 0.003$ & $24.2 \pm 12.7$ \\
\hline 3 Livø Bredning * & - & - & - & - & - & - & - & - \\
\hline 4 Løgstør Bredning & $81 \pm 23$ & $143 \pm 41$ & 0 & 0 & - & $0.3 \pm 0.6$ & $0.002 \pm 0.003$ & $14.0 \pm 0$ \\
\hline 5 Skive Fjord * & - & - & - & - & - & - & - & - \\
\hline \multicolumn{9}{|l|}{ Cruise 3} \\
\hline \multicolumn{9}{|l|}{20 November 2013} \\
\hline 1 Nissum Bredning & $161 \pm 57$ & $284 \pm 100$ & 0 & 0 & - & $14 \pm 5$ & $0.056 \pm 0.034$ & $22.7 \pm 7.7$ \\
\hline 2 Venø Bugt & $363 \pm 77$ & $642 \pm 136$ & 0 & 0 & - & $275 \pm 131$ & $0.435 \pm 0.184$ & $18.4 \pm 7.9$ \\
\hline 3 Livø Bredning & - & - & - & - & - & - & - & - \\
\hline 4 Løgstør Bredning & $247 \pm 150$ & $437 \pm 265$ & 0 & 0 & - & $151 \pm 64$ & $0.400 \pm 0.177$ & $20.7 \pm 7.3$ \\
\hline 5 Skive Fjord & $111 \pm 0$ & $197 \pm 0$ & 0 & 0 & - & $13 \pm 8$ & $0.067 \pm 0.039$ & $23.9 \pm 5.0$ \\
\hline
\end{tabular}

* Jellyfish net lost, ** Beroe gracilis. 
Figure 6. Mnemiopsis leidyi. Oral-aboral length distribution of ctenophores for the five investigated locations in Limfjorden on: (A) 23 September; (B) 23 October; and (C) 20 November 2013. Average densities for each $\mathrm{mm}$ size category are displayed $( \pm \mathrm{SD}$ for the three replicate samples at each location).

A
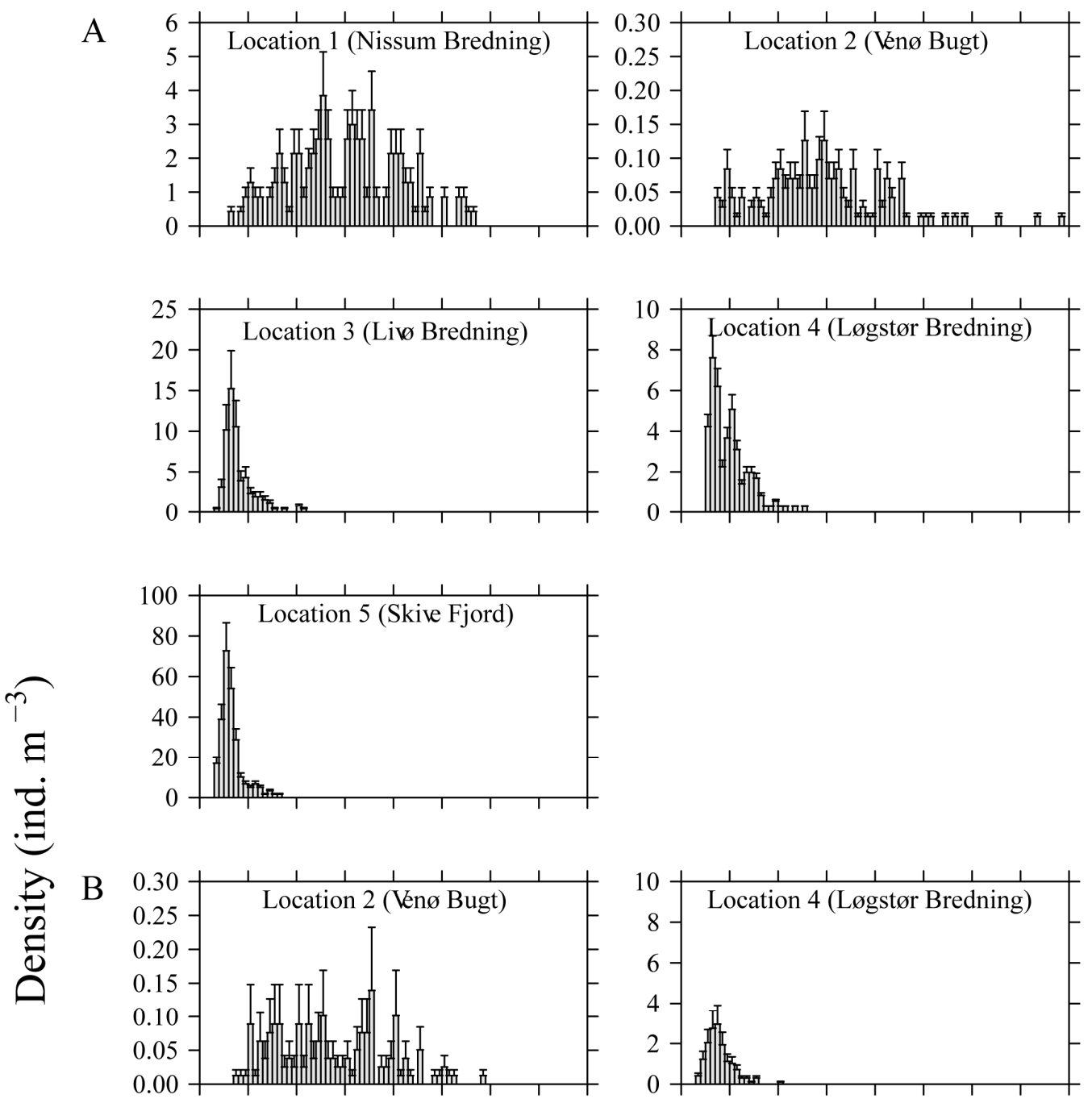

$\mathrm{C}$
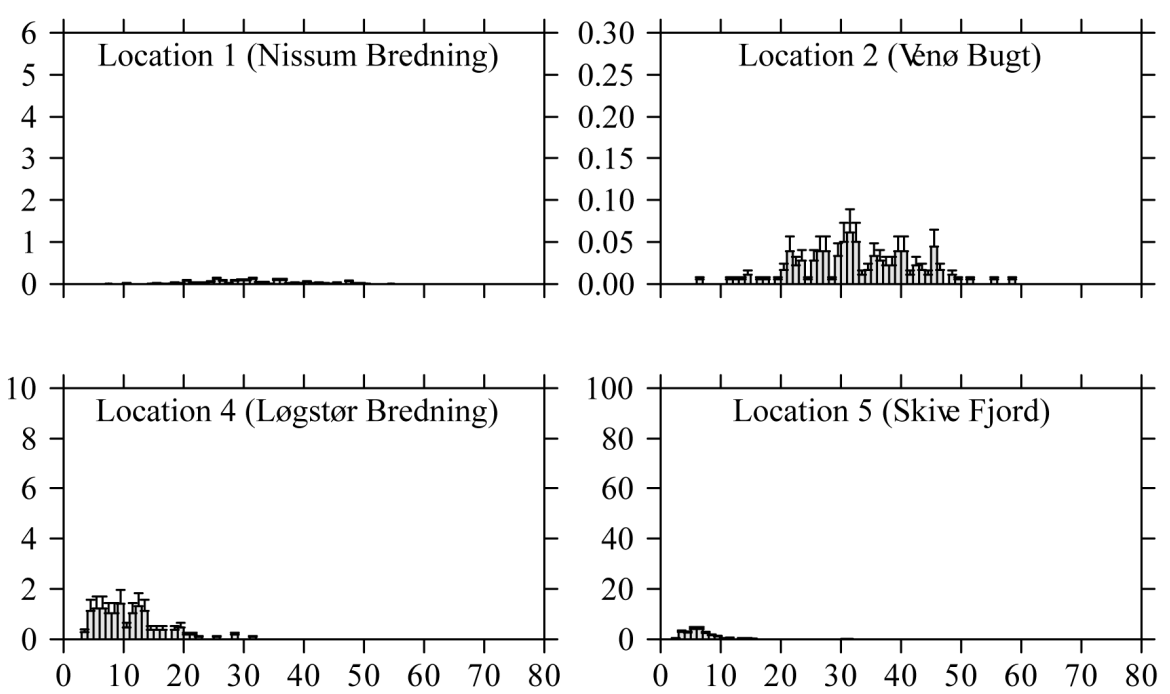

Oral-aboral body length ( $\mathrm{mm})$ 


\subsubsection{Cruises in 2013}

\subsubsection{Cruise 1 (23 September 2013)}

The data for Mnemiopsis leidyi are shown in Table 4 and it appears that the estimated half-life of zooplankton was low in Nissum Bredning and Skive Fjord, 0.5 and 2.1 days, respectively, indicating that this ctenophore controlled the zooplankton community in these parts of Limfjorden. Few Pleurobrachia pileus along with small Beroe gracilis were additionally caught in Nissum Bredning in late September (Table 5). Observations of many large scyphomedusa Rhizostoma octopus stranded on the beaches in Limfjorden, combined with registration of high salinities (up to 32 psu in Nissum Bredning), indicate that strong westerly winds had pushed a large volume of high-saline North Sea water into the fjord system through Thyborøn Kanal, suggesting that M. leidyi was brought into Limfjorden from the North Sea in September 2013 (in the same way as observed in September 2011, cf. Riisgård et al. [8]). From Figure 6A, it appears that the individual size of M. leidyi decreased with increasing distance from the North Sea inlet, allowing for the assumption that central parts of Limfjorden may serve as breeding area for ctenophores, $c f$. Riisgård et al. [8].

Figure 7. Beroe ovata collected in Limfjorden 20 November 2013. Note the prey organism (Mnemiopsis leidyi) in the gastrovascular cavity of the B. ovata in upper right corner (arrow). Photo: Hans Ulrik Riisgård.

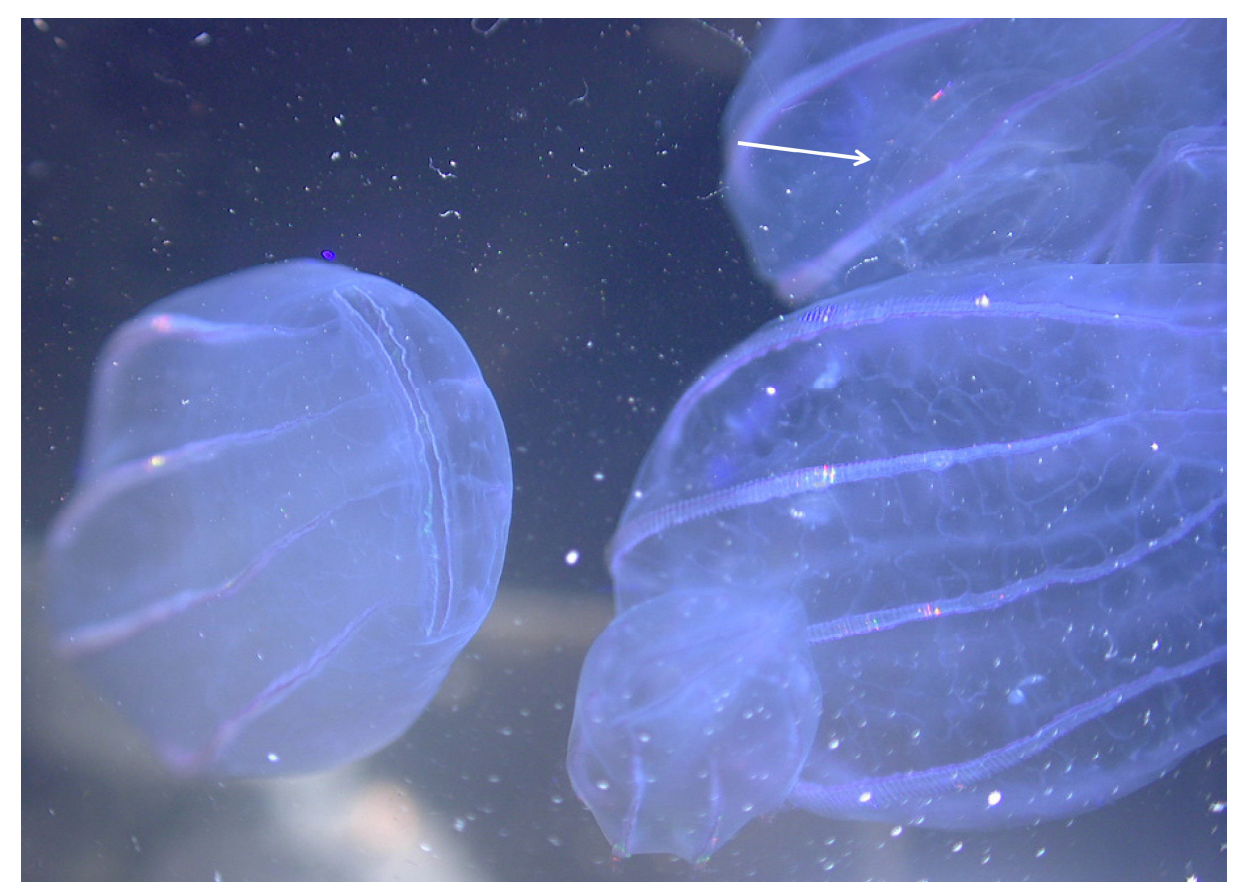

\subsubsection{Cruise 2 (23 October 2013)}

The population density of Mnemiopsis leidyi in Limfjorden decreased from 23 September to 23 October 2013 (Table 4). Larger individuals $(26.7 \pm 11.4 \mathrm{~mm})$ were observed in Venø Bugt, whereas fewer and smaller $(7.4 \pm 2.7 \mathrm{~mm})$ specimens were found in Løgstør Bredning (Figure 6B). It seems likely that the presence of Beroe spp. in both Venø Bugt and Løgstør Bredning (Table 5) had caused or 
contributed to observed declines in the abundance of $M$. leidyi between 23 September (Cruise 1) and 23 October (Cruise 2).

\subsubsection{Cruise 3 (20 November 2013)}

The density of Mnemiopsis leidyi was further reduced (Table 4, Figure 6C), whereas the number of Beroe spp. had strongly increased (Table 5). Three Beroe species were identified (Figures 7 and 8): some smaller individuals $(L<30 \mathrm{~mm})$ were determined to be B. gracilis, an indigenous North Sea ctenophore which, before the arrival of M. leidyi, fed exclusively upon Pleurobrachia pileus [29]; other larger individuals were identified from photos as the native B. cucumis and recently invaded B. ovata [30].

Figure 8. (a) Beroe cucumis; (b) B. gracilis; and (c) mixture of ctenophores (M. leidyi on the left and three individuals of $B$. gracilis on the right frontal view) collected in Limfjorden 20 November 2013. Photo: Hans Ulrik Riisgård.
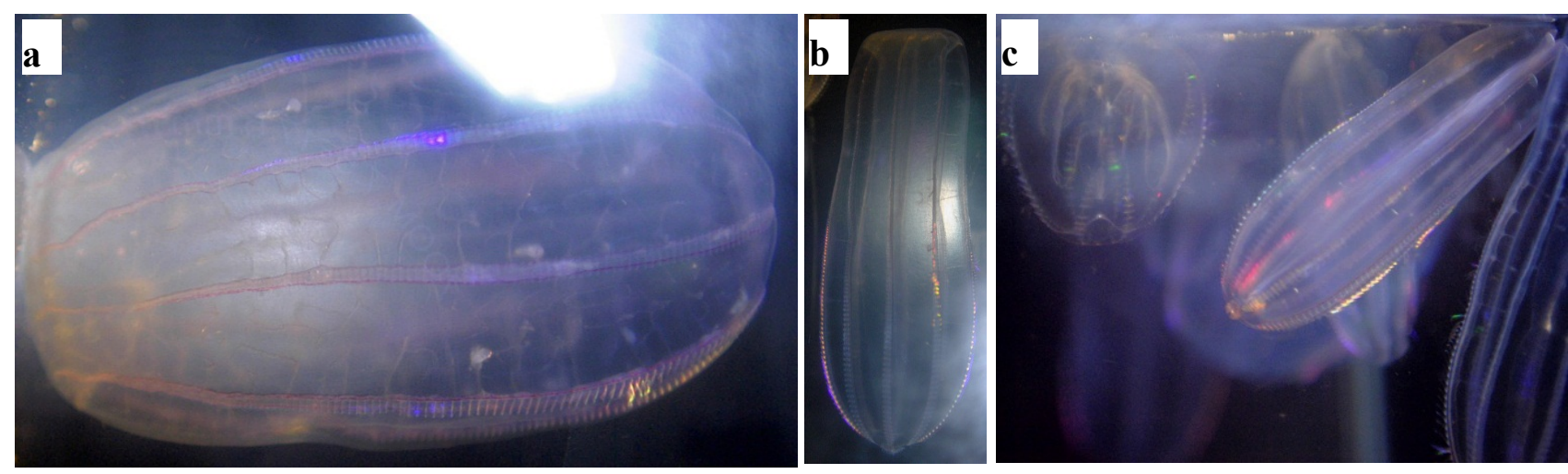

\subsubsection{Ctenophore Species in Limfjorden}

Plerobrachia pileus and Beroe cucumis are known members of Danish marine fauna; B. gracilis frequently appears in the North Sea and Skagerrak, whereas B. ovata is a new species in Limfjorden that was recently observed for the first time in Danish waters (Great Belt) by Shiganova et al. [30]. In Europe, B. ovata was first found in the Black Sea, likely introduced by ballast water, and its native habitat is the coastal waters along Atlantic North and South America (Purcell et al. 2001) [23]. The same species name has been used for morphologically different Beroe species in the Mediterranean (B. ovata sensu Chun) and in the western Atlantic and Caribbean (B. ovata sensu Mayer) [31]. The species now found in Limfjorden is identified morphologically and genetically as B. ovata sensu Mayer 1912 that is known as an invasive species introduced to the Black Sea and the Mediterranean [30]. Mnemiopsis leidyi originates from the northwestern Atlantic [32]. In 2006, it was first recorded in the Baltic Sea, later in the North Sea [24] and, in 2007, it was recorded in large numbers in Limfjorden [15].

\subsubsection{Booms and Busts in Limfjorden}

In both 2012 and 2013, the wind generated west-east with the water current through Limfjorden had apparently (as observed in several previous studies by Riisgård et al. $[8,15,16]$ washed out the 
previously dominating scyphozoan jellyfish Aurelia aurita into Kattegat leaving an "empty niche," allowing for rapid occupation by large numbers of holoplanktonic ctenophores, Pleurobrachia pileus and Mnemiopsis leidyi, initially brought into Limfjorden from the North Sea. In late 2012, P. pileus became the dominating ctenophore with estimated half-life of zooplankton of 1.5 to 2.8 days, whereas M. leidyi dominated in late 2013 when also their predators, Beroe gracilis, B.cucumis and B. ovata, were introduced. This resulted in subsequent declines of the dense $M$. leidyi population, that exerted a pronounced predation impact on the zooplankton during its boom in certain parts of Limfjorden, especially Nissum Bredning and Skive Fjord, in late September 2013. Wind-driven water exchange processes in Limfjorden combined with different life-history strategies of competing gelatinous zooplankton species - A. aurita with an over-wintering benthic polyp stage, and the holoplanktonic $P$. pileus and M. leidyi with fast reproduction and development, along with the occurrence of Beroe spp. predators from the southwestern North Sea and the Dutch Wadden Sea, where they survive the cold winters [25] - may explain observed booms and busts in jellyfish (controlled by washout to Kattegat in the east) and ctenophore (transported into Limfjorden from the North Sea in the west) populations.

\section{Closing Remarks}

Hydrographic observations and model calculations have shown that ctenophores and jellyfish can be brought into Limfjorden via Jutland Coastal Current water from the North Sea, carrying water masses from the English Channel and the southern North Sea [8]. This explains why the abundance of ctenophores and jellyfish in Limfjorden are characterized by often large interannual fluctuations in population size. While the yearly development of Aurelia aurita populations may additionally depend on recruitment via asexual reproduction by local polyp colonies, water exchange processes play a decisive role in the periodical reinvasion by Mnemiopsis leidyi and other ctenophore species from higher saline, warmer offshore waters off the North Sea into Limfjorden. Thus, in cold winters, the southwestern North Sea may serve as a refuge for the invasive M. leidyi [25,26,33,34], subsequently, along with the endemic species Pleurobrachia pileus and its predator Beroe gracilis, re-invading the northern European waters and entering with Jutland Coastal Water via Thyborøn Kanal into Limfjorden which may function as an incubator for $M$. lediyi with the potential to further seed M. leidyi into the Kattegat and adjacent Danish waters [8]. Supporting this hypothesis, the first observation of M. leidyi in Danish waters in 2011 was made in Limfjorden in September. Later, in the period mid-December 2011 to mid-January 2012, M. leidyi was also observed in the Great Belt at the inlet to Kerteminde Fjord where it - along with its natural predator, B. ovata-occurred together with the native ctenophores Bolinopsis infundibulum, B. cucumis, B. gracilis and P. pileus [30]. In the same period, M. leidyi was also observed in Øresund (Cornelia Jaspers, pers. comm.) and Skagerrak (Lene Friis Møller, pers. comm.). The present observation of B. ovata (Figure 7) being a new species in Limfjorden may - due to its predation (e.g., [35]) — decisively change the often impressive number and thus the devastating predation impact of $M$. leidyi that have been described several times since the first occurrence in this fjord system in 2007. Ongoing field studies aim at following this full-scale experiment to document possible ecological consequences on trophic structures in Limfjorden. 
The various jellyfish studies conducted in Limfjorden over the last 10 years have not been made within a common framework for sampling procedure, and the often rather limited number of yearly cruises has obviously not been optimal. Stratification of the water column may affect the distribution of jellyfish and ctenophores particularly in central-southern parts of Limfjorden that are influenced by freshwater inflow from small rivers giving rise to haloclines which, during warm summer periods, may be further stabilized by coincident thermoclines [1], while the shallow (4-8 $\mathrm{m})$ western and central-northern parts are usually less stratified and subject to frequent mixing due to strong westerly winds $[8,9]$. However, possible bias originating from stratification has as of yet not been studied, and although salinity and temperature profiles were measured during earlier samplings, including 2012, the jellyfish-collecting gear did not allow separate samplings below and above a halocline, and therefore, it is not possible to judge if the earlier oblique tows were to be preferred instead of the surface tows used in 2013. Data of the present study were collected during the autumn months, and, despite the application of two different sampling methods, they emphasize that mass occurrence of Mnemiopsis leidyi was correlated with intrusions of North Sea water, additionally underlined by the presence of Rhizostoma and Beroe. Furthermore, we have achieved valuable knowledge about the number of species (see Table 1) and the ecological importance of jellyfish and ctenophores in this fjord system where they frequently occur in extremely large numbers and exert control of the zooplankton biomass, and therefore variations in both phyto- and zooplankton may often remain incomprehensible without complementary knowledge about the joint predation impact of jellyfish and ctenophores on zooplankton which may be strongly reduced (see e.g., [16], Figure 4 therein) releasing the grazing impact on the phytoplankton which may subsequently bloom. One consequence of this is that future environmental and fishing monitoring programs in Limfjorden and other eutrophicated waters should include observations of jellyfish and ctenophores to allow the assessment of their effects. Further, pelagic fish may also be affected by jellyfish and ctenophores. Herring and sprat are pelagic fish species in Limfjorden and they have hitherto been used for both human consumption and processing for fish meal and oil. The herrings enter Limfjorden from both the North Sea in the west and from the Kattegat in the east in late autumn and early winter to spawn in the spring, and the adults leave again in early summer while the juvenile stay (Erik Hoffmann, pers. comm.). Because these fish feed on zooplankton, they may, in certain areas and periods, compete with large numbers of jellyfish and ctenophores. Thus far, however, no studies have attempted to determine the degree of such suggested interspecific competition for zooplankton. The estimated half-lives of zooplankton caused by jellyfish and ctenophores, however, may frequently be rather short, in the order of $<1$ to 2 days (e.g., Tables 2 and $4,[11,15,16])$, thereby creating a pronounced reduction of the zooplankton biomass that may potentially damage the herring populations in Limfjorden.

\section{Acknowledgments}

Thank you to the Danish Nature Agency, Ministry of the Environment, for providing water chemical data, as well as to Gert Pedersen and Svend Åge Bendtsen aboard "Limgrim," Mogens Grimstrup and his crew aboard MHV 902 MANØ (Danish Marine Home Guard), Kim Lundgreen, Ruben van Beek and Florian Lüskow for technical assistance, Tamara Shiganova, who verified the Beroe species from photos and gave constructive comments to an early version of the manuscript, and 
the three anonymous reviewers for constructive suggestions for improvements of the submitted paper. The first author (H.U.R.) was supported by a grant from the Danish Council for Independent Research | Natural Sciences (Grant Number: DFF-4002-00494).

\section{Author Contributions}

H.U.R. participated in the cruises (reported in Section 3) and wrote the manuscript. J.G. took part in the cruises, analyzed the samples and made the tables and plots.

\section{Conflicts of Interest}

The authors declare no conflict of interest.

\section{References}

1. Jørgensen, B.B. Seasonal oxygen depletion in the bottom waters of a Danish fjord and its effect on the benthic community. Oikos 1980, 34, 68-76.

2. Møhlenberg, F. Effect of meteorology and nutrient load on oxygen depletion in a Danish micro-tidal estuary. Aquat. Ecol. 1999, 33, 55-64.

3. Wiles, P.L.; van Duren, L.A.; Häse, C.; Larsen, J.; Simpson, J.H. Stratification and mixing in the Limfjorden in relation to mussel culture. J. Mar. Syst. 2006, 60, 129-143.

4. Hofmeister, R.; Buchard, H.; Bolding, K. A three-dimensional model study on processes of stratification and de-stratification in the Limfjord. Cont. Shelf Res. 2009, 29, 1515-1524.

5. Richardson, K.; Jacobsen, T. Jyllandsstrømmen. En transportmekanisme fra tyske bugt til Kattegat; NPOforskning fra Miljøstyreslsen nr. C6 1990; The Danish Environmental Protection Agency: Copenhagen, Danish, 1990; pp. 68.

6. Aure, J.; Danielsen, D.; Svendsen, E. The origin of Skagerrak coastal water off Arendal in relation to variations in nutrient concentrations. ICES J. Mar. Sci. 1998, 55, 610-619.

7. Gyllencreutz, R.; Backman, J.; Jakobsson, M.; Kissel, C.; Arnold, E. Postglacial palaeoceanography in the Skagerrak. Holocene 2006, 16, 973-983.

8. Riisgård, H.U.; Jaspers, C.; Serre, S.; Lundgreen, K. Occurrence, inter-annual variability and zooplankton-predation impact of the invasive ctenophore Mnemiopsis leidyi and the native jellyfish Aurelia aurita in Limfjorden (Denmark) in 2010 and 2011. BioInvasions Rec. 2012, 1, 145-159.

9. Riisgård, H.U.; Andersen, P.; Hoffmann, E. From fish to jellyfish in the eutrophicated Limfjorden (Denmark). Estuar. Coasts 2012, 35, 701-713.

10. Hoffmann, E. Fisk og fiskebestande i Limfjorden 1984-1999; DFU-rapport nr. 75-00; Danish Institute for Fisheries Research: Dtu, Bygning, Danmark, 2000; pp. 70. (In Danish)

11. Hansson, L.J.; Moeslund, O.; Kiørboe, T.; Riisgård, H.U. Clearance rates of jellyfish and their potential predation impact on zooplankton and fish larvae in a neritic ecosystem (Limfjorden, Denmark). Mar. Ecol. Prog. Ser. 2005, 304, 117-131. 
12. Møller, L.F.; Riisgård, H.U. Feeding, bioenergetics and growth in the common jellyfish Aurelia auritaand two hydromedusae Sarsia tubulosa and Aequorea vitrina. Mar. Ecol. Prog. Ser. 2007, 346, 167-177.

13. Møller, L.F.; Riisgård, H.U. Population dynamics, growth and predation impact of the common jellyfish, Aurelia aurita and two hydromedusae (Sarsia tubulosa and Aequorea vitrina) in Limfjorden (Denmark). Mar. Ecol. Prog. Ser. 2007, 346, 153-165.

14. Møller, L.F.; Riisgård, H.U. Impact of jellyfish and mussels on algal blooms caused by seasonal oxygen depletion and nutrient release from the sediment in a Danish fjord. J. Exp. Mar. Biol. Ecol. 2007, 351, 92-105.

15. Riisgård, H.U.; Bøttiger, L.; Madsen, C.V.; Purcell, J.E. Invasive ctenophore Mnemiopsis leidyi in Limfjorden (Denmark) in late summer 2007-Assessment of abundance and predation effects. Aquat. Invasion 2007, 2, 395-401.

16. Riisgård, H.U.; Madsen, C.V.; Barth-Jensen, C.; Purcell, J.E. Population dynamics and zooplankton-predation impact of the indigenous scyphozoan Aurelia aurita and the invasive ctenophore Mnemiopsis leidyi in Limfjorden (Denmark). Aquat. Invasion 2012, 7, 147-162.

17. Lucas, C.H. Reproduction and life history strategies of the common jellyfish, Aurelia aurita, in relation to its ambient environment. Hydrobiologia 2001, 451, 229-246.

18. Baker, L.D.; Reeve, M.R. Laboratory culture of the lobate ctenophore Mnemiopsis mccradyi with notes on feeding and fecundity. Mar. Biol. 1974, 26, 57-62.

19. Shiganova, T.A.; Dumont, H.J.D.; Mikaelyan, A.S.; Glazov, D.M.; Bulgakova, Y.V.; Musaeva, E.I.; Sorokin, P.Y.; Pautova, L.A.; Mirzoyan, Z.A.; Studenikina, E.I. Interaction between the invading Ctenophores Mnemiopsis leidyi (A. Agassiz) and Beroe ovata Mayer 1912, and their influence on the pelagic ecosystem of the northeastern Black Sea. In The Aquatic Invasions in the Black, Caspian and Mediterranean Seas. NATO ASI Ser 2. Environment; Dumont, H., Shiganova, T., Niermann, U., Eds.; Kluwer Academic Publishers: Dordrecht, The Netherlands, 2004; pp. 33-70.

20. Costello, J.H.; Bayha, K.M.; Mianzan, H.W.; Shiganova, T.A.; Purcell, J.E. Transitions of Mnemiopsis leidyi (Ctenophora: Lobata) from a native to an exotic species: A review. Hydrobiologia 2012, 690, 21-46.

21. Riisgård, H.U. Feeding behaviour of the hydromedusa Aequorea vitrina. Sci. Mar. 2007, 71, 395-404.

22. Tendal, O.S.; Jensen, K.R.; Riisgård, H.U. Invasive ctenophore Mnemiopsis leidyi widely distributed in Danish waters. Aquat. Invasion 2007, 2, 455-460.

23. Purcell, J.E.; Shiganova, T.A.; Decker, M.B.; Houde, E.D. The ctenophore Mnemiopsis in native and exotic habitats: U.S. estuaries versus the Black Sea basin. Hydrobiologia 2001, 451, 145-176.

24. Faasse, M.A.; Bayha, K.M. The ctenophore Mnemiopsis leidyi A. Agassiz 1865 in coastal waters of the Netherlands: An unrecognized invasion? Aquat. Invasion 2006, 1, 270-277.

25. Boersma, M.; Malzahn, A.M.; Greve, W.; Javidpour, J. The first occurrence of the ctenophore Mnemiopsis leidyi in the North Sea. Helgol. Mar. Res. 2007, 61, 153-155.

26. Ginderdeuren, K.V.; Hostens, K.; Hoffman, S.; Vansteenbrugge, L.; Soenen, K.; Blauwe, H.D.; Robbens, J.; Vincx, M. Distribution of the invasive ctenophore Mnemiopsis leidyi in the Belgian part of the North Sea. Aquat. Invasion 2012, 7,163-169.

27. Møller, L.F.; Canon, J.M.; Tiselius, P. Bioenergetics and growth in the ctenophore Pleurobrachia pileus. Hydrobiologia 2010, 645, 167-178. 
28. Decker, M.B.; Breitburg, D.L.; Purcell, J.E. Effects of low dissolved oxygen on zooplankton predation by the ctenophore Mnemiopsis leidyi. Mar. Ecol. Prog. Ser. 2004, 280, 163-172.

29. Greve, W. Ctenophora. Fiches Identif. Zooplanct. 1975, 146, 1-6.

30. Shiganova, T.; Riisgård, H.U.; Ghabooli, S.; Tendal, O.S. First report on Beroe ovata in an unusual mixture of ctenophores in Great Belt (Denmark). Aquat. Invasion 2014, 9, 111-116.

31. Bayha, K.M.; Harbison, G.R.; Mcdonald, J.H.; Gaffney, P.M. Preliminary investigation on the molecular systematic of the invasive ctenophore Beroe ovata. In The Aquatic Invasions in the Black, Caspian and Mediterranean Seas. NATO ASI Ser 2. Environment; Dumont, H., Shiganova, T., Niermann, U., Eds.; Kluwer Academic Publishers: Dordrecht, The Netherlands, 2004; pp. 167-175.

32. Ghabooli, S.; Shigasnova, T.; Zahn, A.; Cristesu, M.E.; Eghtesadi-Araghi, P.; MacIsaae, H.J. Multiple introductions and invasion pathways for the invasive ctenophore Mnemiopsis leidyi in Eurasia. Biol. Invasions 2011, 13, 679-690.

33. Van Walraven, L.; Langenberg, V.T.; van der Veer, H.W. Seasonal occurrence of the invasive ctenophore Mnemiopsis leidyi in the western Dutch Wadden Sea. J. Sea Res. 2013, 82, 86-92.

34. Hamer, H.H.; Malzahn, A.M.; Boersma, M. The invasive ctenophore Mnemiopsis leidyi: A threat to fish recruitment in the North Sea? J. Plankton Res. 2011, 33, 137-144.

35. Finenko, G.A.; Romanova, Z.A.; Abolmasova, G.I.; Anninsky, B.E.; Svetlichny, L.S.; Hubareva, E.S.; Bat, L.; Kideys, A.E. Population dynamics, ingestion, growth and reproduction rates of the invader Beroe ovata and its impact on plankton community in Sevastopol Bay, the Black Sea. J. Plankton Res. 2003, 25, 539-549.

(C) 2014 by the authors; licensee MDPI, Basel, Switzerland. This article is an open access article distributed under the terms and conditions of the Creative Commons Attribution license (http://creativecommons.org/licenses/by/4.0/). 